\title{
Comparison of Lithium Concentration in Serum, Plasma and Erythrocytes
}

\author{
Mateja Grizelj ${ }^{1}$, Danijel Crnković ${ }^{2}$, Lidija Kostanjšak ${ }^{3}$, Nada Vrkić ${ }^{4}$, \\ Dalibor Karlović ${ }^{2}$ \\ ${ }^{1}$ Varažin Institute of Public Health, Varaždin, Croatia \\ ${ }^{2}$ Department of Psychiatry, Sestre milosrdnice University Hospital Center, Zagreb, Croatia \\ ${ }^{3}$ Acute Psychiatric Unit, University Hospital Campus, Ennis, Co. Clare, Ireland \\ ${ }^{4}$ Department of Medical Biochemistry and Hematology, University of Zagreb, Zagreb, \\ Croatia
}

\begin{abstract}
The use of lithium in medicine began in the mid-19th century, when the solubility of uric acid salts in the solution of lithium carbonate was demonstrated in vitro, which meant that lithium could be used in the treatment of gout. The use of lithium in psychiatry starts in 1949, when the effect of lithium in the treatment of mania was demonstrated. The mechanism of action of lithium is not yet completely understood. In parallel with the use of lithium in the treatment of psychiatric disorders, different methods for the determination of lithium in human samples have been developed. The first aim of the study was to determine the amount of lithium in serum samples using electrochemical methods, flame photometry and spectrophotometry and use the results to compare the results obtained using these methods. Because of the possibility of determining lithium in various media, the second aim of the study was to evaluate the clinical value of determining the concentration of lithium in erythrocytes in relation to the concentration of lithium in plasma. The third aim was to investigate the extent to which a therapeutic dose of lithium correlates with the measured concentrations of lithium in serum, plasma and erythrocytes. It was concluded that statistically there was no significant difference between the three test laboratory methods $(P=0.507)$. Investigating the correlation between the concentration of lithium in various media measured by different methods and the daily therapeutic dose of lithium, it was concluded that statistically a significant correlation was found only in serum lithium concentrations measured with electrochemical method $(P=0.009 ; r=0.47)$. There was statistically a significant moderate correlation between the concentration of lithium in plasma and erythrocytes $(P=0.002 ; r=-0.54)$, and the lithium concentration erythrocytes are higher than lithium concentrations in plasma $(P=0,043)$. The range of the ratio of the concentration of lithium in erythrocytes and plasma is wide (13.25 to 111.15), and is not in correlation with the therapeutic daily dose and therefore is not a better indicator in the control of the treatment.
\end{abstract}

Keywords: lithium ion-selective electrodes, flame photometry, spectrophotometry

Copyright (ㅇ 2017 KBCSM, Zagreb

e-mail: alcoholism.kbcsm@gmail.com•www.http//hrcak.srce.hr/acoholism

Correspondence to: Dalibor Karlović

Department of Psychiatry, Sestre milosrdnice University Hospital Center, Vinogradska 29, Zagreb, Croatia

E-mail: dalibor.karlovic@gmail.com 


\section{Introduction}

The use of lithium in medicine began in the mid-19th century. Lithium was first used to treat gout.

The use of lithium in psychiatry starts in 1949, in the treatment of acute depression and acute mania. The US Food and Drug Administration (FDA) approved the use of lithium to treat mania in $1970[8,18]$. Today, lithium is used in the treatment of bipolar disorder, depressive disorder and schizophrenia [22]. Lithium is absorbed from the gastrointestinal tract within six to eight hours. Peak plasma concentrations are achieved 1-2 hours or 5-6 hours after administration, depending on whether it is a fast or slow release form, but peak concentrations in the brain are achieved 2 hours after the peak of plasma concentrations. Lithium is excreted in the urine. Elimination half-life is 20 hours [11]. The exact mechanism of action of lithium as a mood stabilizer is still unknown, despite numerous studies that have been conducted. Lithium has short and long term effects on cells of the central nervous system, the signaling pathway and there is also a lot of evidence that lithium changes neural plasticity by acting on apoptotic mechanisms [19]. Lithium has an effect on the following enzymes: inositol monophosphate, inositol-1-plilfostfat phosphatase; glycogen synthase kinase-3; bisphosphate nucleotidase, fructose-1,6.bifosfatase and phosphoglucomutase [22]. Because lithium is toxic, and also has a narrow therapeutic range, it is very important to monitor lithium concentrations in body fluids, plasma and serum or in cells. The therapeutic range for lithium in serums is from $0.6 \mathrm{mmol} / \mathrm{L}$ to $1.2 \mathrm{mmol} /$ L. Measurement of lithium levels in serum is carried out 12 hours after the last dose. The toxic concentration of lithium in se- rum is above $1.5 \mathrm{mmol} / \mathrm{L}$. The methods used today to determine lithium concentration are spectrophotometry, electrochemical methods (ion-selective electrodes - ISE) and atomic absorption spectrometry (AAS). The aim of this study was to measure the concentration of lithium by different methods and in different human samples: serum, plasma and erythrocytes and to determine which one is the most reliable for assessing therapeutic width as a function of the applied dose of lithium.

\section{Subjects and Methods}

\section{Subjects}

The study included 41 psychiatric patients, with diagnosed bipolar disorder, schizoaffective disorder, schizophrenia and depression. The psychiatric diagnose was determined by using DSM 5 as criterion. The group consisted of 12 women and 29 men with ages ranging from 32 to 76 . The criterion for inclusion was the presence of lithium therapy for a specific psychiatric disorder. The study involved patients who, due to lithium treatment should control the concentration of lithium in blood and for the purposes of this study we used their residual venous blood samples. All venous blood sampling was conducted 12 hours after the last dose of lithium, as the physician prescribed the routine medical procedures. This test did not have any effect on the laboratory or therapeutic method for patients. Two tubes of $3 \mathrm{ml}$ volume venous blood were taken from each patient. One tube of blood that was drawn into the tubes without anticoagulant was used for the recovery of serum, while other tube of venous blood was taken in a test tube containing an anticoagulant K3EDTA (ethylenediamine- 
tetraacetic acid) and was used to obtain the plasma and hemolysate.

\section{Laboratory procedures}

In venous blood samples hematocrit levels (HTC) were determined by the hematology analyzers DxH, Beckman Coulter (Miami, USA) and Sysmex XE1000i (Kobe, Japan). Venous blood samples, used for serum preparation, were stored at room temperature for $30 \mathrm{~min}$, as it is required to complete the process of spontaneous blood clotting, and then were centrifuged for $10 \mathrm{~min}$, with the power of the centrifuge of 3500 rotations / minute (r/min) at room temperature. From the venous blood samplesthat were used to acquire plasma, we first isolated $0.5 \mathrm{ml}$ of blood to acquire hemolysate. The $0.5 \mathrm{ml}$ ofisolated blood for hemolysate preparation was mixed with $2 \mathrm{ml}$ of double-distilled water and thereby obtained a sample of hemolysate in which we determined the concentration of lithium. The remaining blood samples were immediately centrifuged for $10 \mathrm{~min}$ with the centrifugal force of $3500 \mathrm{r} / \mathrm{min}$, at room temperature. After centrifugation, the separated plasma sample of $0.5 \mathrm{~mL}$ was mixed with 2 $\mathrm{ml}$ of double-distilled water. In these diluted plasma samples we determined the concentration of lithium. Lithium concentrations in serum samples were determined using spectrophotometry on the machine VITROS 250, (Johnson \& Johnson, New Jersey). The exact principle of the method is achieved by using a multi-layer film (Vitros Li Slide). On the top of the film the machine pipetted $10 \mu \mathrm{L}$ sample in which it is necessary to determine the amount of lithium. The sample passes to the lower film layer where lithium in the sample specifically binds to the azo dye with which it forms a colored complex and the in- tensity of color complex formed is measured at a wavelength of $600 \mathrm{~nm}$ with spectrophotometric method. Lithium concentrations in serum samples were determined on the machine Rosche Cobas Integra 400 (Rotkreuz, Switzerland). This electrochemical method using ion-selective electrodes can not be used to determine the concentration of lithium in the hemolysate due to interference of hemoglobin, neitherfor determining lithium concentrations in plasma due to the interference of EDTA. All hemoglobin levels higher than $0.06 \mathrm{mmol} / \mathrm{L}$ in a sample significantly interfere with the determination of the concentration of lithium. The exact mechanism of interference of hemoglobin and EDTA with ion-selective electrode apparatus Rosche Cobas Integra 400 is not available, because the part of the membrane which provides selectivity for lithium is still protected by a patent. Lithium concentrations in serum, plasma and hemolysate, by flame photometry, were determined on the machine IL943.

\section{Statistical methods}

To show the results and statistical data we used computer programs Excel 2010, Microsoft Office (Microsoft USA) and statistical program MedCalc in. 13.3. (MedCalc Software, Mariakerke, Belgium). We presented the characteristics of the test group of patients and the ratio of concentrations in erythrocytes and plasma obtained by flame photometry using descriptive analysis. Datasets were tested with the Kolmogorov-Smirnov statistical test for normality of distribution. Correlation coefficients were interpreted according to Colton. We used the model of linear regression to estimate the dependent variable in relation to the prediction factor on a level of statistical significance of $\mathrm{P}<0.05$. 


\section{Results}

The group of 41 patients, aging from 32 to 76 years, did not have a balanced proportion of men $(\mathrm{N}=29)$ and women $(\mathrm{N}=12)$, as shown in Figure 1. The subjects had been diagnosed with different mental disorders. 30 patients were diagnosed with bipolar disorders, 3 patients had been diagnosed with schizophrenia, 3 patients were treated for schizoaffective disorder, one patient was diagnosed with depression, and 4 patients had no diagnosis recorded. The group of patients also differed in the daily dose of lithium prescribed. The total daily intake of lithium for 30 patients was in the range from $600 \mathrm{mg}$ to $1800 \mathrm{mg}$ of lithium daily.

\section{Comparison of methods}

The first aim of this study was to compare the concentration of lithium in the serum obtained using three different methods: using spectrophotometry, electrochemical methods

Table 2. This table shows the age of patients, the daily therapeutic dose of lithium, lithium concentration in plasma and erythrocytes measured by flame photometry and the concentration of lithium in serum measured by flame photometry, electrochemical method and the method of spectrophotometry.

\begin{tabular}{|c|c|c|c|c|c|c|c|}
\hline & $\mathrm{N}$ & Median & $95 \%$ CI & Minimum & Maximum & $25-75 \mathrm{P}$ & $\mathrm{P}$ \\
\hline Age & 41 & 45 & $43-53$ & 32 & 76 & $39-58$ & 0.2370 \\
\hline $\begin{array}{l}\text { Daily dose } \\
\text { of } \mathrm{Li}(\mathrm{mg})\end{array}$ & 30 & 900.0 & $900.0-900.0$ & 600.0 & 1800.0 & $750.0-900.0$ & 0.0005 \\
\hline $\begin{array}{l}\text { Concentration of } \\
\mathrm{Li} \text { in erythrocytes } \\
(\mathrm{mmol} / \mathrm{L})\end{array}$ & 31 & 0.78 & $0.56-0.97$ & 0.37 & 1.55 & $0.52-1.10$ & 0.194 \\
\hline $\begin{array}{l}\text { Concentration } \\
\text { of } \mathrm{Li} \text { in plasma } \\
(\mathrm{mmol} / \mathrm{L})\end{array}$ & 31 & 0.67 & $0.56-0.80$ & 0.40 & 0.94 & $0.51-0.82$ & 0.008 \\
\hline $\begin{array}{l}\text { Concentration of } \\
\mathrm{Li} \text { in serum- PF } \\
(\mathrm{mmol} / \mathrm{L})\end{array}$ & 31 & 0.71 & $0.62-0.83$ & 0.29 & 1.02 & $0.56-0.89$ & 0.424 \\
\hline $\begin{array}{l}\text { Concentration of } \\
\mathrm{Li} \text { in serum- ISE } \\
(\mathrm{mmol} / \mathrm{L})\end{array}$ & 41 & 0.60 & $0.50-0.70$ & 0.23 & 1.00 & $0.44-0.77$ & 0.113 \\
\hline $\begin{array}{l}\text { Concentration of } \mathrm{Li} \\
\text { in serum - Vitros } \\
(\mathrm{mmol} / \mathrm{L})\end{array}$ & 23 & 0.49 & $0.43-0.62$ & 0.18 & 0.97 & $0.38-0.63$ & 0.444 \\
\hline
\end{tabular}

$\mathrm{N}$ - number of patients; CI - reliability interval of $95 \% ; 25-75 \mathrm{P}$ - the range of variables from 25th to 75th percentiles; P - level of statistical significance ; PF - flame photometry, ISE - ion-selective elektrode; Vitros - spectrophotometry. 


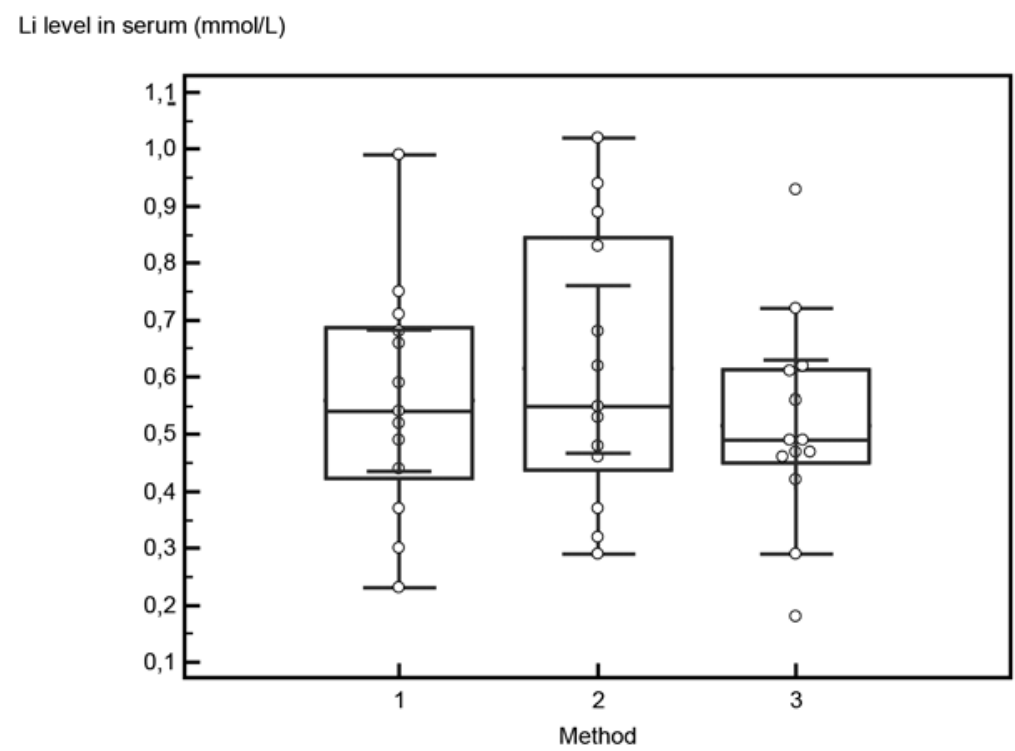

Figure 2. The comparison of lithium levels in serum measured using three different methods; 1-ion-selective electrode, 2 flame photometry, 3-spectrophotometry; $\mathrm{P}=0.507$.

and flame photometry. The serum concentration of lithium using all three methods was determined on 13 samples and statistically analysed, using the ANOVA test. It was found that there was statistically no significant difference between the three methods used $(\mathrm{P}=0.507)$.

\section{Determination of lithium in erythrocytes}

The second aim of this study was to compare the calculated concentration of lithium in erythrocytes to plasma concentration and make an assessment of the clinical value of determining the concentration of lithium in erythrocytes compared to plasma. The concentration of lithium in erythrocytes is calculated using the measured concentrations of lithium in the hemolysate and plasma by flame photometry. The values of lithium in erythrocytes are calculated using a mathematical model [17].

$$
\text { Conc. of } \mathrm{Li} \text { in } \mathrm{Erc}(\mathrm{mmol} / \mathrm{L})=\frac{(\mathrm{Li} \text { level in blood }-\mathrm{Li} \text { level in plasma })(1-\mathrm{Htc})}{\mathrm{Htc}}
$$

The ratio of lithium in erythrocytes and in plasma can be calculated using the concentration of lithium in the erythrocytes [17].

$$
\text { Conc.of } \mathrm{Li} \text { in Erc / conc.of Li in plasma }=\frac{\text { conc. of } \mathrm{Li} \text { in } \mathrm{Erc}(\mathrm{mmol} / \mathrm{L}) \times 100}{\text { conc.of } \mathrm{Li} \text { in plazmi }(\mathrm{mmol} / \mathrm{L})}
$$


Table 3. Concentration of $\mathrm{Li}$ in plasma and erythrocytes measured with flame photometry, hematocrit, and the ratio of the concentration of lithium in erythrocytes and in plasma.

\begin{tabular}{lccccccc}
\hline & $\mathrm{N}$ & Median & $95 \% \mathrm{CI}$ & Minimum & Maximum & $25-75 \mathrm{P}$ & $\mathrm{P}$ \\
\hline $\begin{array}{l}\text { Concentration } \\
\text { of Li in plasma } \\
\text { (mmol/L) }\end{array}$ & 31 & 0.67 & $0.56-0.80$ & 0.40 & 0.94 & $0.51-0.82$ & 0.008 \\
$\begin{array}{l}\text { Concentration of } \\
\text { Li in erythrocytes } \\
\text { (mmol/L) }\end{array}$ & 31 & 0.78 & $0.56-0.97$ & 0.37 & 1.55 & $0.52-1.10$ & 0.194 \\
$\begin{array}{l}\text { Hematocrit (L/L) } \\
\text { Erc/P }\end{array}$ & 31 & 0.437 & $0.423-0.455$ & 0.351 & 0.516 & $0.413-0.458$ & 0.918 \\
& 31 & 31.00 & $23.30-40.16$ & 13.25 & 111.15 & $20.50-47.85$ & 0.001
\end{tabular}

$\mathrm{N}$ - number of patients; CI - reliability interval of $95 \%$; $25-75 \mathrm{P}$ - the range of variables from 25th to 75 th percentiles; $\mathrm{P}$ - level of statistical significance.

Reviewing the ratio of the concentration of lithium in erythrocytes and plasma, which is quite a wide range of values $(13.25$ to 111.15), we can conclude that lithium con- centrations in red blood cells do not fully reflect the concentration of lithium in plasma.

There was statistically a significant, moderate correlation between the concentration

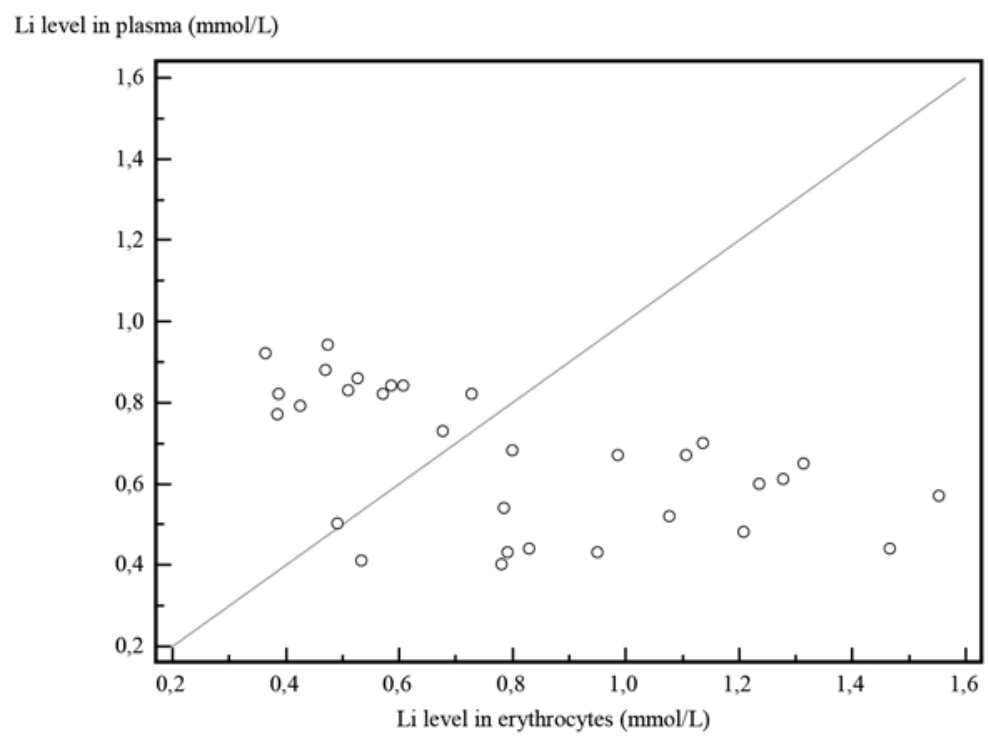

Figure 3. Correlation of lithium levels in plasma and in erythrocytes; $\mathrm{P}=0.002 ; \mathrm{r}=-0.54$. 


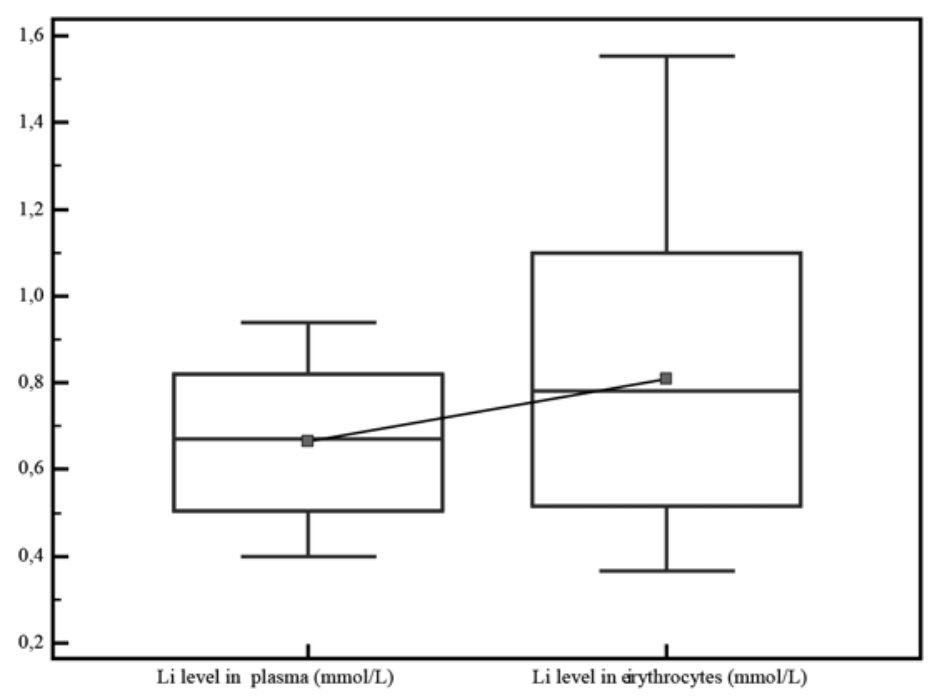

Figure 4. Comparison of the concentration of potassium in the plasma and the red blood cells measured by flame photometry; $\mathrm{P}=0.043$.

of lithium in plasma measured with the flame photometer and the calculated concentration of lithium in erythrocytes $(\mathrm{P}=0.002 ; \mathrm{r}=$ 0.54).

Comparison of the concentration of lithium in plasma and erythrocytes was evaluated by using the parametric t-test because of the normal distribution. Among them there is statistically a significant difference $(\mathrm{P}$ $=0.043)$, and we conclude that the value of lithium in erythrocytes is significantly higher than in plasma.

The correlation between a therapeutic dose of lithium to lithium concentrations in serum, plasma and erythrocytes

In this study we evaluated the correlation of lithium levels in serum, plasma and red blood cells and the therapeutic doses of lithium. As a limit for determining statistical significance, we used $\mathrm{P}<0.05$. 


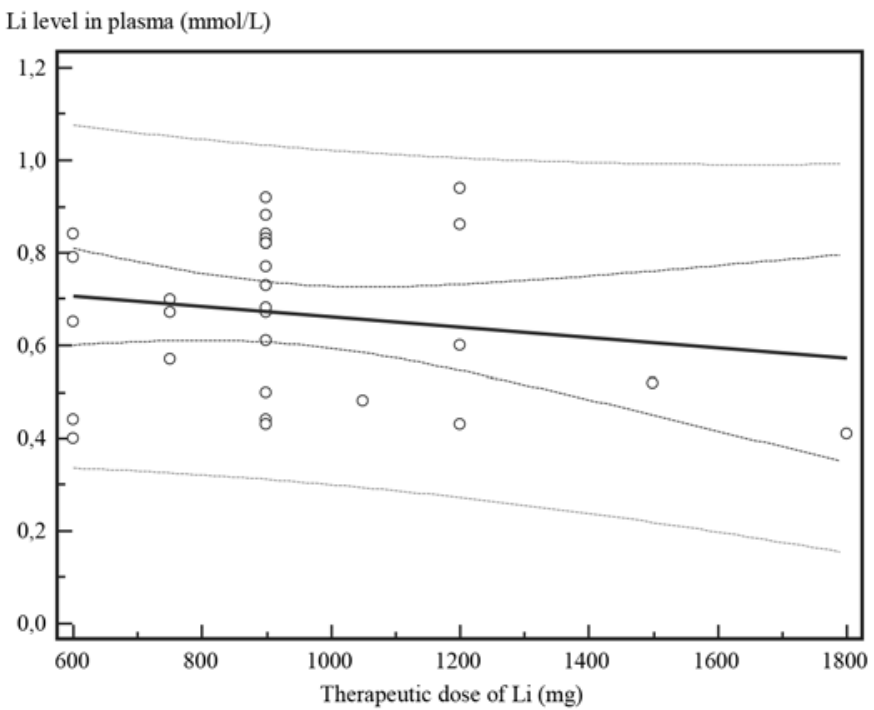

Figure 5. Correlation of lithium concentrations in plasma measured by flame photometry and the therapeutic dose of lithium; $\mathrm{P}=0.932 ; \mathrm{r}=-0.02$

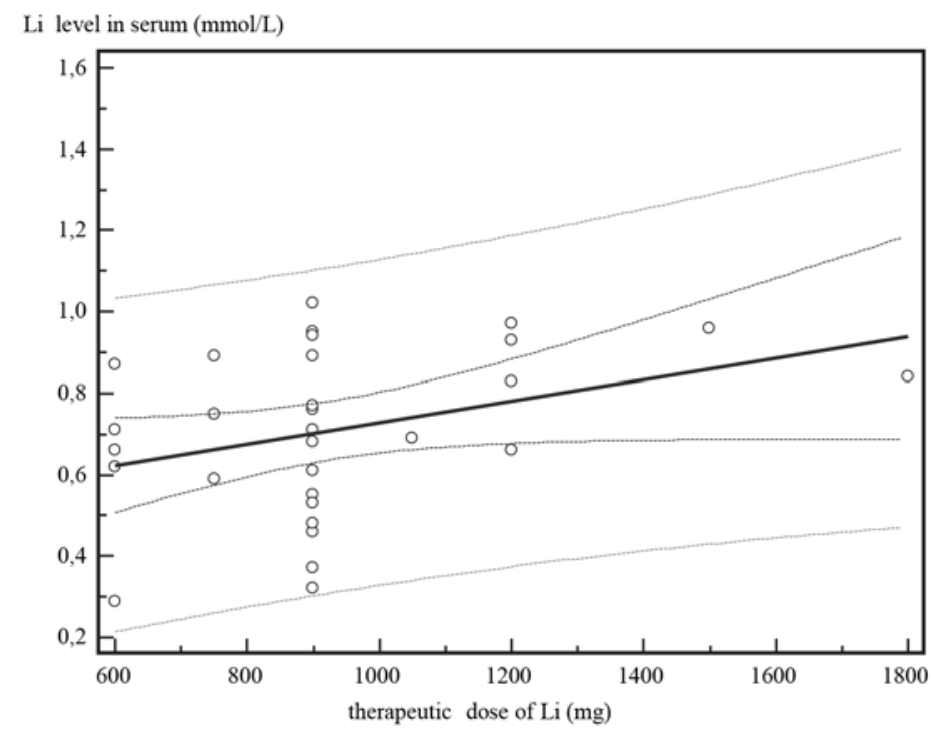

Figure 6. Correlation of serum lithium concentrations measured by flame photometry with the therapeutic dose of lithium; $\mathrm{P}=0.078 ; \mathrm{r}=0.34$ 
Li level inb serum $(\mathrm{mmol} / \mathrm{L})$

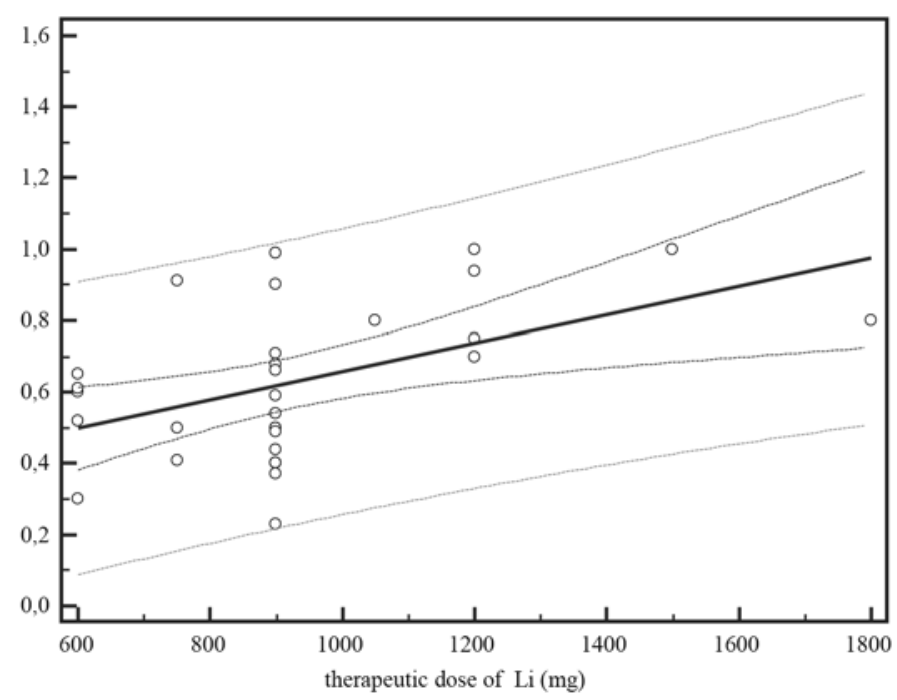

Figure 7. Correlation of serum lithium concentrations measured with the electrochemical method and the therapeutic dose of lithium; $\mathrm{P}=0.009 ; \mathrm{r}=0.47$

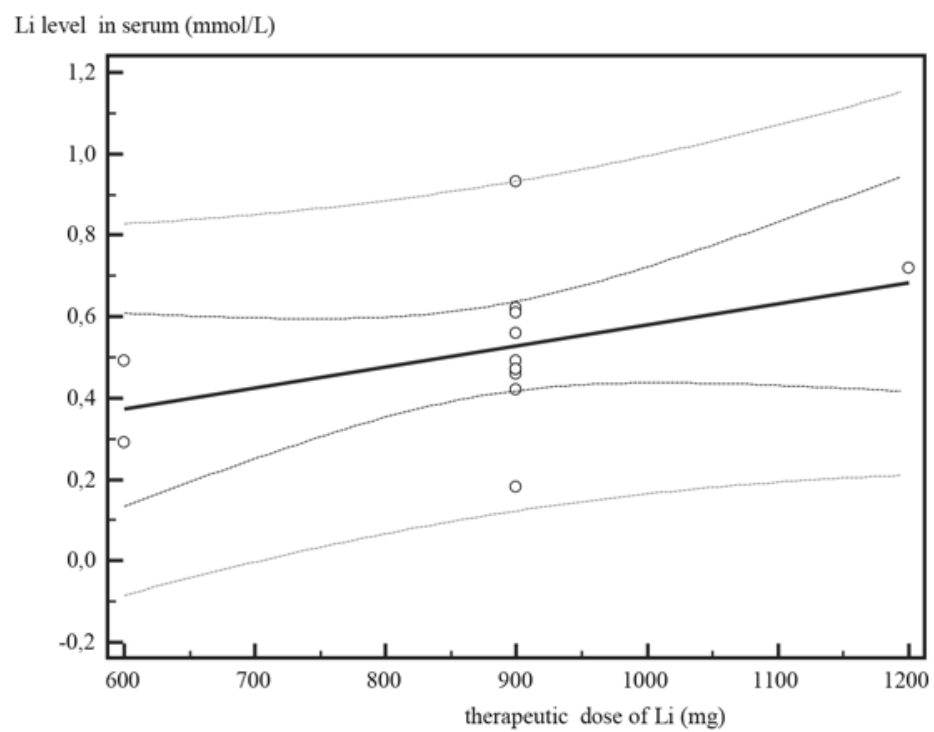

Figure 8. Correlation of the concentration of lithium in serum measured by spectrophotometry method and the therapeutic dose of lithium; $\mathrm{P}=0.167 ; \mathrm{r}=0.41$ 


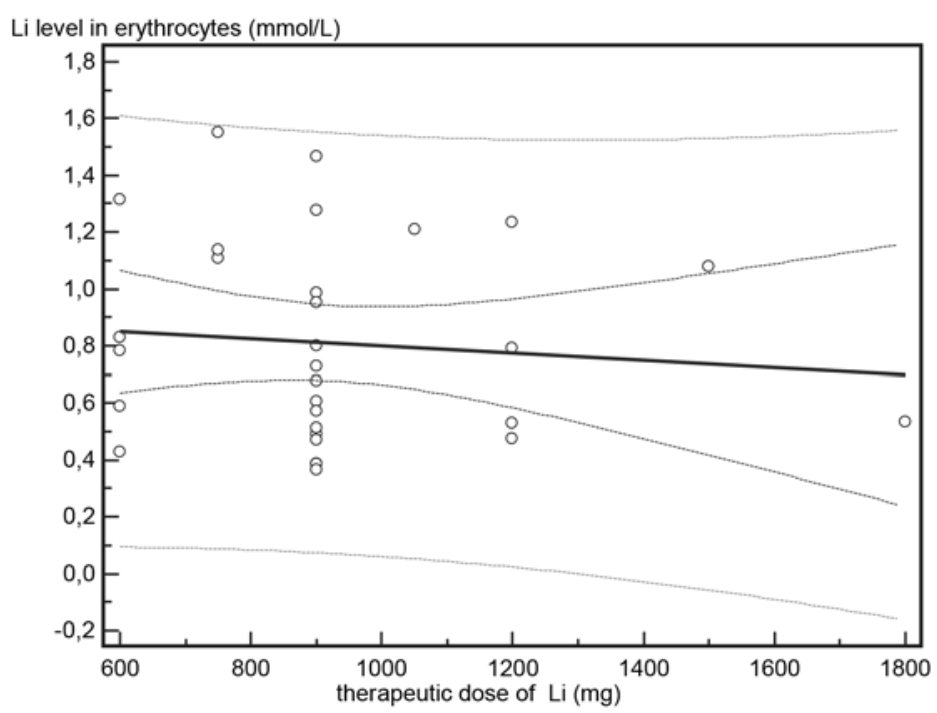

Figure 9. Correlation of lithium concentrations in red blood cells and the therapeutic dose of lithium; $\mathrm{P}=0.526 ; \mathrm{r}=-0.12$.

Table 4. Correlation of therapeutic dose of lithium to the concentration of lithium in different samples measured using three different methods.

\begin{tabular}{|c|c|c|c|}
\hline Sample & method & $\mathrm{r}$ & $\mathrm{P}$ \\
\hline serum & $\mathrm{PF}$ & 0.34 & 0.078 \\
\hline serum & ISE & 0.47 & 0.009 \\
\hline serum & VITROS & 0.41 & 0.167 \\
\hline plasma & $\mathrm{PF}$ & -0.02 & 0.932 \\
\hline erythrocytes & $\mathrm{PF}$ & -0.12 & 0.526 \\
\hline$(\mathrm{Erc} / \mathrm{P})$ & summary & -0.10 & 0.61 \\
\hline
\end{tabular}

PF - flame photometry; ISE - electrochemical method, ion selective electrode; VITROS - spectrophotometry; $\mathrm{r}$ - correlation coefficient according to Colton; P - level of statistical significance 
Concentrations of lithium in plasma and in erythrocytes do not correlate with the therapeutic dose of lithium or the ratio of the concentration of lithium in plasma and erythrocytes. The serum concentrations are positive dose-related. The higher the doses the higher are the concentrations. But this correlation cannot be subordinated to linear regression $(\mathrm{r}=0.34 ; \mathrm{r}=0.41 \mathrm{r}=0.47)$. The correlation coefficients are low (rating by Colton), and statistically significant only in the electrochemical methods ( $\mathrm{P}=0.009)$.

It can be concluded that the concentration of lithium in serum determined by using the electrochemical method best correlates with a daily dose of lithium.

\section{Discussion}

As the use of lithium in medicine began it was important to develope methods for determining the concentration of lithium in the blood of patients for follow-up treatment, in order to avoid side effects and toxicity and to reduce relapses. Lithium has a narrow therapeutic range and the reference range for lithium concentrations in serum and plasma, in patients who are treated with lithium compounds is between $0.6 \mathrm{mmol} / \mathrm{L}$ to $1.2 \mathrm{mmol} / \mathrm{L}$. Concentrations above 1.5 $\mathrm{mmol} / \mathrm{L}$ are considered toxic. Therapeutic lithium overdose, due to its narrow therapeutic range, is more frequent than an overdose as a result of deliberate or accidental intake of large quantities of the drug. The first signs of poisoning are gastrointestinal symptoms (nausea, vomiting, diarrhea), muscle weakness, impaired coordination, drowsiness or lethargy, even ataxia, dizziness, blurred vision, tinnitus, disorientation, muscle cramps, and larger amounts of diluted urine. If the concentration of lithium in the blood in- creases above 2-3 mmol / L patients may present with disorientation and convulsions, coma and death. In the 1970s the importance of the determination of the concentration of lithium in erythrocytes and the ratio of the concentration of lithium in erythrocytes and in plasma as a possible prognostic indicators was realized, due to the assumption that the concentration of lithium in erythrocytes better reflects the concentration of lithium in the brain and the neurons.

There was an assumption that there might be four ways of lithium entry into erythrocytes: passive diffusion, diffusion with bicarbonate ions, lithium replacing sodium in the system $\mathrm{Na}+/ \mathrm{K}+$-ATPase (adenosine triphosphatase) on the cell membrane and release of lithium from the cell in exchange for sodium. It is considered that because of the way lithium enters into erythrocytes, the concentration of lithium in erythrocytes is a better indicatior of the concentration of lithium in neurons and therefore the determination of lithium in erythrocytes should enter the laboratory practices [10]. The results of this study showed statistically significant, moderate correlation $(\mathrm{P}=0.002 ; \mathrm{r}=-0.54)$ between plasma concentrations of lithium and the lithium concentration in erythrocytes, which is consistent with other studies of this type.

Statistically significant, good to excellent correlation, $(\mathrm{P}<0.0001, \mathrm{r}=0.81)$, of the lithium concentration in plasma and the erythrocytes, resulting in the work of authors Camus et al., 2003. The concentrations of lithium therein, were determined by atomic absorption spectrometry and the research was conducted on a larger number of samples, to be precise on 309 blood samples collected from 165 patients who were treated with lithium. Compared to this study, which was conduct- 
ed on a quite smaller number of samples, the difference was also in the processing of samples before the analysis of lithium in erythrocytes.

The authors of this article hemolyzed erythrocytes by using $7 \mathrm{ml}$ of sterile water (containing no lithium) and $2 \mathrm{ml}$ of trichloroacetyl acid which was used for the precipitation of proteins from a sample and the samples were then mixed, centrifuged and the supernatant analyzed. The match of the results of more studies, which were conducted by different laboratory methods and different sample processing, confirmed the expected correlation between the concentration of lithium in plasma and erythrocytes. However, due to longer sample processing and more human labour needed in determining the concentration of lithium in erythrocytes, this method probably will never get into the routine laboratory practice because it is much easier and faster to obtain serum or plasma with the centrifuge and thus monitor the concentration of lithium in blood. In this work (Camus et al., 2003), authors also investigated the contribution of calculating the concentration of lithium in erythrocytes and in plasma in differentiating the acute from chronic lithium poisoning. The authors came to the conclusion that the ratio of concentrations of lithium in erythrocytes and in plasma is higher in chronic poisoning than in acute poisoning with lithium, which is expected due to the mechanism of lithium entry into erythrocytes. The authors came to the conclusion that this ratio could be used in differentiating acute from chronic lithium poisoning and to decide which therapeutic action to use. In this paper, the authors made a comparison of ratio between the concentration of lithi- um in erythrocytes and in plasma from different samples and concluded that there are significant differences in the ratios between the samples of individual patients (13.25 to 111.15) which is also in line with recent research $[17,4]$.

In this study, it was concluded that there was no statistically significant difference between the three test methods used for determining the concentration of lithium $(\mathrm{P}=$ 0.507): spectrophotometry, flame photometry and ion-selective electrodes. The flame photometer, which was used in this study (IL943) is no longer used in laboratory practice because of an unstable flame system and consequently it required frequent calibration and also because of the development of new methods and machines which achieve a better level of automation, but it can be concluded that this machine compared with modern technology achieves good results. Some papers state that the concentration of lithium obtained by ion-selective electrode is higher than the concentration of lithium obtained by flame photometry and atomic absorption spectroscopy [1], but this research has not produced a statistically significant difference between the tested methods. In this paper, we made a comparison of lithium concentration in serum, plasma and red blood cells with the daily doses of lithium taken by patients.A statistically significant but low correlation was found only when comparing the concentration of lithium in serum obtained by ion-selective electrode with therapeutic doses of lithium ( $\mathrm{P}=0,009 ; \mathrm{r}=0.47$ ). Comparing therapeutic doses of lithium to lithium concentrations in serum obtained by flame photometry and spectrophotometry, the concentration of lithium in plasma obtained by flame photometry and the calculated concentration of lithium in erythrocytes 
were not significant correlated. The results may lead to the conclusion that patients do not adhere to prescribed therapy, however, such a conclusion can not be safely set. Comparing the three methods, spectrophotometry, electrochemical methods and flame photometry, which were used for determining of the concentration of lithium in serum samples, it was concluded that there was no statistically significant difference between the three methods $(\mathrm{P}=0.507)$. Lithium concentrations analyzed by electrochemical methods could be determined only in serum samples due to the interference of hemoglobin (the sample hemolysate) and the interference of EDTA (for plasma sample). Using spectrophotometric methods hemoglobin interferes due to the influence of the hemoglobin color in the part of spectrum in which lithium is being measured $(600 \mathrm{~nm})$. Flame photometry can determine the concentration of lithium in all tested media, but this method has other shortcomings (lack of complete automation, often calibration of the machine, etc.), and therfore it is no longer in the routine laboratory practice. Lithium concentrations measured using flame photometer are higher in erythrocytes than in plasma $(\mathrm{P}=0.043)$. There was a modest but statistically significant correlation between plasma and eryth-

\section{References}

1. Aliasgharpour M, Hagani H. Evaluation of lithium determination in three analyzers: flame emission, flame atomic absorption spectroscopy and ion selective electrode. N Am J Med Sci. 2009;1:244-6.

2. Berridge MJ, Downes CP, Hanley MR. Neural and developmental actions of lithium: a unifying hypothesis. Cell. 1989;59:411-9. rocyte concentrations $(\mathrm{P}=0.002 ; \mathrm{r}=-0.54)$. The ratio of the concentration of lithium in the erythrocytes and in the plasma did not indicate that there is regularity in the distribution of lithium between plasma and cells. The range of ratios is very wide (13.25 to 111.15) and is not in correlation to the therapeutic daily dose and therefore is not a better indicator in the control of the treatment. It was concluded that only lithium concentrations in serum measured by electrochemical method correlate with the daily dose of lithium $(\mathrm{P}=$ $0.009 ; \mathrm{r}=0.47$ ), while the concentrations in plasma and erythrocytes do not correlate with the daily dose and neither does the ratio of the concentration of lithium in plasma and erythrocytes. It was confirmed that serum is the best sample for measuring the concentration of lithium and that the electrochemical method of determining the concentration of lithium in serum correlates best with a daily dose of lithium.

\section{Acknowledgments}

None

\section{Conflict of interest}

None to declare
3. Berridge MJ. Inositol trisphosphate and calcium signalling mechanisms. Biochim Biophys Acta.2009; 1793:933-4.

4. Camus M, Henneré G, Baron G, Peytavin G, Massias L, Mentré F, Farinotti R. Comparison of lithium concentrations in red blood cells and plasma in samples collected for TDM, acute toxicity, or acute-on-chronic toxicity. Eur J Clin Pharmacol. 2003;59:583-7. 
5. Can A, Schulze TG, Gould TD. Molecular actions and clinical pharmacogenetics of lithium therapy. Pharmacol Biochem Behav. 2014; doi:10.1016/j. pbb.2014.02.004.

6. Clevers $H$, Nusse R. Wnt/ $\beta$-catenin signaling and disease. Cell. 2012;149:1192-205.

7. DeBattista C. Antidepresivi. U: Temeljna i klinička farmakologija. Klarica M, Trkulja V, ŠalkovićPerišić M., editors. Zagreb: Medicinska naklada; 2011. p. 509-13.

8. El-Mallakh RS, Jefferson JW. Prethymoleptic Use of Lithium. Am J Psychiatry. 1999;156:29.

9. Fayard E, Tintignac LA, Baudry A, Hemmings BA. Protein kinase B/Akt at a glance. J Cell Sci. 2005;118:5675-8.

10. Frazer A, Mendels J, Brunswick D, London J, Pring $\mathrm{M}$, Ramsey TA, et al.Erythrocyte concentrations of the lithium ion: clinical correlates and mechanisms of action. Am J Psychiatry. 1978;135:10659.

11. Freeman M, Gelenberg AJ, Wiegand CB. Lithium. U: The American Psychiatric Publishing Textbook of Psychopharmacology. Schatzberg AF, Nemeroff CB, editors. USA: 2009;. p. 697-717.

12. Fukumoto T, Morinobu S, Okamoto Y, Kagaya A, Yamawaki S. Chronic lithium treatment increases the expression of brain-derived neurotrophic factor in the rat brain. Psychopharmacology. 2001; 158: 100-6.

13. Haugeto $\varnothing$, Ullensvang K, Levy LM, Chaudhry FA, Honoré T, Nielsen $M$, et al. Brainglutamate transporter proteins form homomultimers. J Biol Chem. 1996;271: 27715-22.

14. Hilgemann DW, Feng S, Nasuhoglu C. The complex and intriguing lives of PIP2 with ion channels and transporters. Sci STKE. 2001.

15. Hisayasu GH, Cohen JL, Nelson RW. Determination of plasma and erythrocyte lithium concentrations by atomic absorption spectrophotometry. Clinical Chemistry. 1977;23:41-5.
16. Jakopec S, Karlović D, Dubravčić K, Batinić D, Sorić J, Brozović A et al. Lithium effect on glutamate induced damage in glioblastoma cells. Coll Antropol. 2008;1:87-91.

17. Jasenovec N, Kasum S, Kobe M, Kustrin M, Malešić I, Piskar M, et al. Izabrani postupci analiza u kliničko biokemijskim laboratorijima. 1988.

18. Jefferson JW, Greist JH. Lithium. U: Comprehensive textbook of psychiatry. Kaplan HI, Sadock BJ, editors, Baltimore, Maryland, USA: 1995; p. 202231.

19. Karlović D. Apoptoza - mogući patofiziološki mehanizam u poremećajima raspoloženja kojeg mijenjaju litijeve soli. Biochemia Medica. 2008;18:291310.

20. Klein PS, Melton DA. A molecular mechanism for the effect of lithium on development. Proc Natl Acad Sci U S A. 1996;93:8455-9.

21. Martucci L, Wong AHC, De Luca V, Likhodi O, Wong GWH, King N, et al. Nmethyl-D-aspartate receptor NR2B subunit gene GRIN2B in schizophrenia and bipolar disorder: polymorphisms and mRNA levels. Schizophr Res. 2006;84:214-21.

22. Meltzer H. Antipsihotici i litij. U: Temeljna i klinička farmakologija. Klarica M, Trkulja V, Šalković-Perišić, editors. Zagreb: Medicinska naklada; 2011, p. 487-507.

23. Osten P, Stern-Bach Y. Learning from stargazin: the mouse, the phenotype and the unexpected. Curr Opin Neurobiol. 2006;16:275-80.

24. Ryves WJ, Harwood AJ. Lithium inhibits glycogen synthase kinase- 3 by competition for magnesium. Biochem Biophys Res Commun. 2001;26;280:7205.

25. Severino G, Congiu D, Serreli C, De Lisa R, Chillotti C, Del Zompo M, et al. A48G polymorphism in the $\mathrm{D} 1$ receptor genes associated with bipolar I disorder. Am J Med Genet B Neuropsychiatr Genet. $2005 ; 134: 37-8$. 


\section{Uspoređivanje koncentracije litija u serumu, plami i eritrocitima}

Sažetak- Primjena litija u medicini započela je sredinom 19. stoljeća kada je in vitro prikazana topljivost soli mokraćne kiseline u otopini litijeva karbonata što je ukazalo na činjenicu da se litij može koristiti u liječenju gihta. Korištenje litija u psihijatriji započinje 1949. godine kada je dokazan njegov učinak u liječenju manije. Njegov mehanizam djelovanja još nije u potpunosti razjašnjen. Paralelno s korištenjem litija u liječenju psihijatrijskih poremećaja razvile su se različite metode za određivanje koncentracije litija u ljudskim uzorcima. Prvi cilj studije bio je odrediti razinu litija u uzorcima seruma koristeći elektrokemijske metode, plamenu fotometriju, spektrofometriju i usporediti rezultate s rezultatima dobivenim korištenjem ovih metoda. Zahvaljujući mogućnosti određivanja litija u raznim medijima, drugi cilj studije bio je procijeniti kliničke vrijednosti određivanja koncentracije litija u eritrocitima u odnosu na koncentraciju litija u plazmi. Treći cilj bio je istražiti u kojoj se mjeri terapijska doza litija podudara s izmjerenim koncentracijama litija u serumu, plazmi i eritrocitima. Zaključeno je da statistički ne postoji značajna razlika između tri laboratorijske metode (P.= 0.507). Istražujući povezanost između koncentracije litija u raznim medijima izmjerenim različitim metodama i dnevne terapeutske doze litija, zaključeno je da je statistički značajna poveznica pronađena jedino u izmjerenoj koncentraciji litija u serumu pomoću elektrokemijske metode (P $00.009 ; r=0.47)$. Statistički je značajna umjerena povezanost između koncentracije litija u plazmi i eritrocitima ( $(P=0.002 ; r=-0.54)$, i koncetracije litija u eritrocitima su veće od koncentracije litija u plazmi $(P=0,043)$. Raspon udjela koncentracije litija u eritrocitima i plazmi je širok (13.25 do 111.15) i nije povezan s terapeutskom dnevnom dozom i stoga nije bolji indikator u kontroli tretmana.

Ključne riječi: litijske ion selektivne elektrode, plamena fotometrija, spektrofometrija 